\title{
Preliminary research on adaptability of municipalities in the sub- basin of Nysa Kłodzka using multidimensional comparative analysis
}

\author{
Grzegorz Dumieński ${ }^{1, *}$, Agnieszka Mruklik $^{2}$, Andrzej Tiukało ${ }^{1}$, and Alicja Lisowska ${ }^{3}$ \\ ${ }^{1}$ Institute of Meteorology and Water Management - National Research Institute, Parkowa 30, 51-616 Wrocław, Poland \\ ${ }^{2}$ Wrocław University of Environmental and Life Sciences, Department of Mathematics, Grunwaldzka 53, 50-375 Wrocław, Poland \\ ${ }^{3}$ University of Wrocław, Institute of Political Science, Koszarowa 3, 51-149 Wrocław, Poland
}

\begin{abstract}
The aim of this article is to present a preliminary assessment of the adaptability of Polish municipalities to the flood hazard. In the conducted studies municipalities were understood not only as basic local government units in Poland, but also as social-ecological systems. The study covered 18 municipalities situated in the sub-basin of Nysa Kłodzka. This region has suffered from numerous floods in the past, and adverse consequences in the form of material losses as well as in human victims let us acknowledge this part of Poland to be one of the most threatened by floods. The analyses used data available in the public domain (mainly from the Statistics Poland database; Polish abbr. GUS) as well as obtained using the questionnaire created for this purpose. The preliminary studies on adaptability of the municipalities in the area of the sub-basin of Nysa Kłodzka have been conducted using the data form the period of 2010-2016. The starting point for conducting a multidimensional comparative analysis, and at the same time the selection of 110 gained diagnostic variables describing 18 determinants of SES adaptability to flood hazard was the identification of 2 main factors determining SES' adaptability (its adaptive potential and adaptive capacity), and 4 categories of determinants of its adaptability (human capital and social potential, financial potential, ecological potential and organizational potential). The initial selection of the diagnostic variables was made using the Pearson correlation coefficient. The proposed logic of aggregation and selection of these variables can be adapted for the adaptability studies on other territorial units and for study on their adaptability to different kinds of threats.
\end{abstract}

\section{Introduction}

The projection of climate changes alleged, among others, in global reports of IPCC [1], and in Poland, e.g. in the reports of the project CLIMATE [2] or in the City Plans of Climate Change Adaptation (Polish abbr. MPA) [3] unambiguously confirm that one should prepare for increase in the frequency and intensity of natural phenomena, especially floods.

In Poland the municipality performs the statutory prerogatives regarding flood protection at the local level [4], and it is the basic unit of local government (LGU). The municipality is also an entity participating in the implementation of the assumptions of the socalled flood directive [5]. On its basis, the Flood Risk Assessment was carried out in Poland (also at the municipal level), the Maps of Flood Hazard (MFH, Polish abbr. MZP), Maps of Flood Risk (MFR, Polish abbr. MRP) were prepared, as well as the Flood Risk Management Plans for the River Basin Areas and Water Regions (FRMP, Polish abbr. PZRP) [6]. Hierarchizing municipalities in relation to particular categories of flood hazard (in FRMP, there are 4 identified: health and life of citizens, economic activity, environment and cultural heritage) it was recognized that all municipalities in Poland are characterized by the same level of adaptability to the flood hazard. The authors take the view that such a methodical assumption is wrong because the municipalities in Poland understood as socialecological systems (SES) are characterized by different adaptive potential and have different adaptive capacity.

Adaptability of the municipality as the SES threatened by flood indicates (current) systems' ability to limit the adverse consequences of floods [7]. This ability is constantly changing as a result of the adaptation process. The main factors determining the adaptability of the municipality-SES threatened by flood is: the adaptive potential taking into account the quantity and quality of resources the municipality can provide, and adaptive capacity meaning the municipality's ability to activate its resources for rational flood risk management [7].

The aim of the article is to present the preliminary assessment of adaptability of municipalities located in the sub-basin of Nysa Kłodzka to the flood hazard, using multidimensional comparative analysis.

\footnotetext{
Corresponding author: grzegorz.dumienski@imgw.pl
} 
For this purpose, a synthetic adaptation index (SAI) has been developed. Authors concern those municipalities not only as the basic LGUs in Poland, but also as independent working social-ecological systems (SES) [7, 8].

Development of methodology for assessing the adaptability of municipalities as the SES to flood hazard will allow hierarchy (ranking) of these units due to various characteristics (determinants) characterizing these municipalities.

Therefore, the conducted analyses constitute a non-technical issue of the development of flood risk protection methods aimed at categorizing local government units in terms of adaptation to flood hazard, as well as rational targeting of assistance sometimes constituting a strategic state intervention towards those units where the adverse consequences of flood cause long term SES (municipality) dysfunctions.

\section{The research area}

The river Nysa Kłodzka with its length of $182 \mathrm{~km}$ constitutes left-bank tributary of Oder - one of the main rivers of Poland. It wells up from the Śnieżnik Massif, then it flows through the Kłodzko Structural Basin, the Sudety Foreland and the Silesian Lowland. In terms of the territorial division of Poland, the Nysa Kłodzka river's sub-basin flows through 18 municipalities (figure 1). Those basic administrative units which in turn belong to 5 counties and 2 voivodeships: Dolnośląskie and Opolskie. Basic information on municipalities in terms of: territorial division and flood hazard, were posted in the table 1. The analysis of MFH and MFR, as well as assigned particular levels of flood risk which were determined as the part of the FRMP project indicated that the municipalities located in the sub-basin of Nysa Kłodzka have high and very high level of flood risk (table 1).

Numerous historic floods, huge material losses and human losses, aspire the discussed region as the area particularly threatened to flood occurrence and vulnerable to their adverse consequences. This was an important reason for undertaking research on the assessment of the SES' adaptability for the municipalities located in this very region.

The analysis of MFR and MFH indicated, among others, that within the area of discussed sub-basin there are approximately 15 thousand people threatened by the flood waters with the probability $(p)$ of occurrence $1 \%$ (the so-called one hundred year water). With such probability of occurrence of flood the area of potential flooding, in particular municipalities, varies from around 1 to $30 \%$ of total areas of those municipalities, and the lost assets (potential flood losses) from around 10 to over $145 \mathrm{mln}$ PLN (table 1).

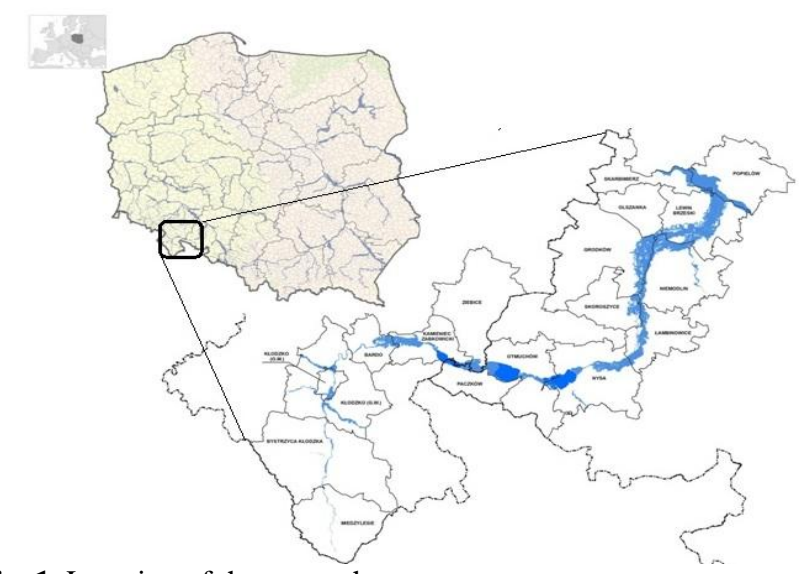

Fig. 1. Location of the research area [source: own work].

It should be noted that in historical terms the flood affected the area of sub-basin of Nysa Kłodzka on average every 10 years [9]. Huge losses and the number of people directly threatened by flood caused current implementation of strategic investments in this region as the part of the Oder River Basin Flood Protection Project [10]. Funds for financing the project come from, among others, the International Bank for Reconstruction and Development of the World Bank, those investments are to minimalize the adverse consequences of flood in this region in the future [10].

\section{Materials and methods}

Operationalization of the term social-ecological system (SES) in the context of specificity of the Polish municipality [7] as a basic LGU threatened by flood allowed to determine 2 main factors determining the adaptability of the SES - the adaptive potential and adaptive capacity. These factors affect the categories of SES' adaptability, 4 of which were identified in the conducted research: K1 - human capital and social potential, K2 - financial potential, K3 - ecological potential and $\mathrm{K} 4$ - organizational potential. It was recognized that the ecological potential, economical potential, as well as human capital and social potential affect the adaptive potential, while organizational potential, human capital and social potential - on the adaptive capacity. 
Table 1. Municipalities of the sub-basin of Nysa Kłodzka according to the applicable administrative division along with the assigned level of integrated flood risk set out in FRMP.

\begin{tabular}{|c|c|c|c|c|c|c|c|}
\hline \multirow[t]{2}{*}{ No. } & \multicolumn{3}{|c|}{ Administrative division } & \multicolumn{2}{|c|}{$\begin{array}{l}\% \text { of hazard } \\
\text { (with probability } p \text { of flood } \\
\text { occurrence equal to } 1 \% \text { the } \\
\text { so-called } 100 \text { year water) }\end{array}$} & \multirow{2}{*}{$\begin{array}{l}\text { Potential } \\
\text { flood } \\
\text { losses in } \\
\text { mln PLN }\end{array}$} & \multirow[t]{2}{*}{$\begin{array}{c}\text { The level of } \\
\text { intergrated } \\
\text { flood risk }\end{array}$} \\
\hline & municipality & county & $\begin{array}{c}\text { voivode- } \\
\text { ship } \\
\end{array}$ & $\begin{array}{c}\text { municipal } \\
\text { citizens }\end{array}$ & $\begin{array}{c}\text { municipal } \\
\text { area }\end{array}$ & & \\
\hline 1 & Międzylesie (s.m.) & \multirow{4}{*}{ kłodzki } & \multirow{7}{*}{ 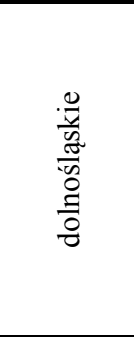 } & 1.8 & 0.5 & 7.4 & moderate \\
\hline 2 & Bystrzyca Kłodzka (s.m.) & & & 2.6 & 0.8 & 23.6 & very high \\
\hline 3 & Kłodzko (r.m.) & & & 19.4 & 4.5 & 149.8 & very high \\
\hline 4 & Kłodzko (u.m.) & & & 6.7 & 17.1 & 42.4 & very high \\
\hline 5 & Bardo (s.m.) & \multirow{3}{*}{$\begin{array}{l}\text { ząbkowi- } \\
\text { cki }\end{array}$} & & 14.3 & 10.8 & 39.6 & very high \\
\hline 6 & Kamieniec Ząbkowicki (r.m.) & & & 16.4 & 15.9 & 46.2 & very high \\
\hline 7 & Ziębice (s.m.) & & & 0.9 & 2.7 & 8.6 & moderate \\
\hline 8 & Paczków (s.m.) & \multirow{5}{*}{ nyski } & \multirow{11}{*}{$\frac{\frac{0}{0}}{\frac{a}{0}}$} & 3.7 & 2.8 & 26.4 & high \\
\hline 9 & Otmuchów (s.m.) & & & 2.0 & 5.4 & 9.3 & moderate \\
\hline 10 & Nysa (s.m.) & & & 1.3 & 7.6 & 42 & very high \\
\hline 11 & Łambinowice (r.m.) & & & 2.7 & 13.2 & 21.5 & high \\
\hline 12 & Skoroszyce (r.m.) & & & 0.1 & 7.8 & 5.3 & moderate \\
\hline 13 & Niemodlin (s.m.) & \multirow{2}{*}{ opolski } & & 3.4 & 12.2 & 26.8 & high \\
\hline 14 & Popielów (r.m) & & & 0.1 & 12.0 & 8.8 & very high \\
\hline 15 & Grodków (s.m.) & \multirow{4}{*}{ brzeski } & & 2.7 & 9.1 & 27 & high \\
\hline 16 & Olszanka (r.m.) & & & 0.0 & 2.0 & 1.1 & low \\
\hline 17 & Lewin Brzeski (s.m.) & & & 25.0 & 28.5 & 104.3 & very high \\
\hline 18 & Skarbimierz (r.m.) & & & 2.2 & 16.0 & 13.4 & high \\
\hline
\end{tabular}

Types of municipalities in Poland: r.m. - rural municipality (commune), s.m. - suburban municipality, u.m. - urban municipality [source: own work based on the data from the FRMP project and information from the SP database].

The designation of 4 main categories of municipality's adaptability describing this feature of the SES allowed to diagnose the determinants of SES adaptability. In the conducted analyses 15 determinants of municipality's adaptability to flood hazard were separated together (figure 2). This choice constituted a starting point for searching for data in the public domain which would enable a comprehensive diagnosis and the broadest possible description of the chosen determinant of the SES adaptability to the flood hazard. It was also guided by the principle saying that these determinants should include main attributes of the social system and ecological system, as well as point the current and anticipated challenges accompanying the functioning of the SES [7].

It has been assumed that particular determinants of SES adaptability will be described by diagnostic variables (indicators). It was also assumed that all the diagnostic variables have the same impact on the assessment of adaptability.

The diagnostic variables, meaning the basic indicators describing a given determinant of SES adaptability, were first sought in two independent areas:

1. literature of the subject, among others: [11, 12],
2. the public domain, i.e. data based on information from the basis of the Statistics Poland (SP; Polish abbr. GUS) - the Bank of Local Data (BLD; Polish abbr. BDL) and Statistic Vademecum of Local Government (SVLG; Polish abbr. SVS), data gained from Supreme Chamber of Nurses and Midwives (SCNM, Polish abbr. NIPiP), The Polish Chamber of Physicians and Dentists (PCPD; Polish abbr. NIL), County Sanitary and Epidemiological Stations (CSES; Polish abbr. PSSE), information from the websites of City Halls or Municipal Offices, Databases of Topographic Objects (DTO, Polish abbr. BDOT), Maps of Flood Hazard (MFH), Maps of Flood Risk (MFR) and the results of the FRMP project [6].

Some determinants have been represented by numerous diagnostic variables, others indicated their insufficiency or lack. Due to these disproportions a decision has been made to create and acquire the values of new diagnostic variables, especially for category K4 and determinants D13-D15, which showed insufficient indicators. For this purpose, a special questionnaire has been developed. 


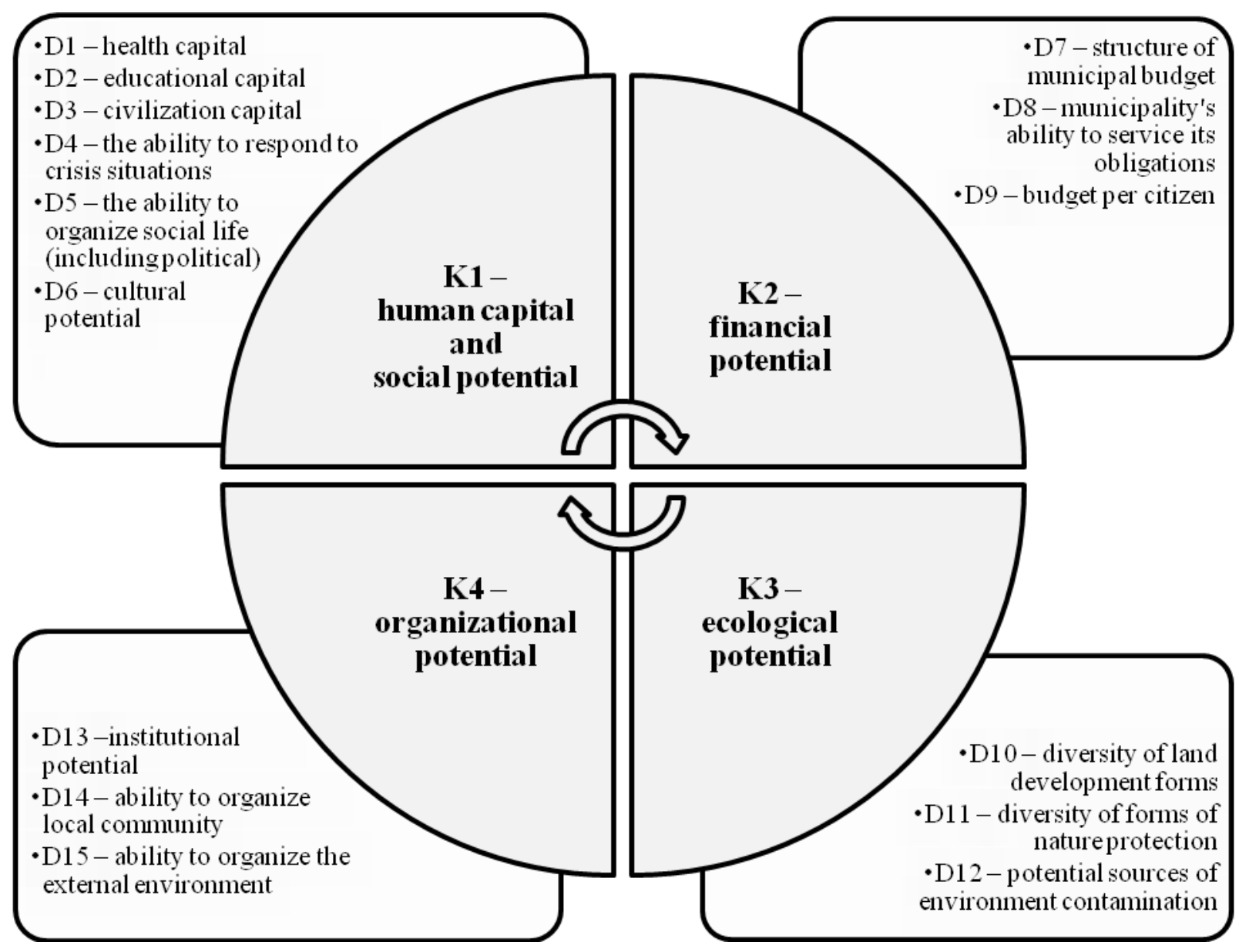

Fig. 2. Determinants of SES adaptability ordered in four categories [source: own work].

It was sent to the officials working in the municipalities located in the sub-basin of Nysa Kłodzka, who are responsible for making decisions concerning flood protection and crisis management. All respondents answered, unfortunately not always those were full answers.

The data set concerns the years 2010-2016. This way a set of 110 elements was created, a set of potential diagnostic variables $X_{j}, j=1, \ldots, 110$ and the values of these variables were obtained in particular years. The statistical material was initially prepared by the method of overall overview. Next, using the arithmetic average, the realizations implementation of diagnostic variables was averaged. It is a way to perform, among others, in the classic approach to multidimensional comparative analysis (MCA) [13-17]. Such data one can present in the form of indicator matrix.

MCA methods are statistical methods allowing comparison of different objects, i.e. voivodeships, while taking into account many of the features characterizing them, such as demographic or economic indicators [18-20]. MCA methods are used to study complex directly unmeasured phenomena characterizing determined objects subject to analysis. These objects should create relatively homogeneous set. Initially the MCA based solely on historical data in the form of time series. The arithmetic averages of characteristics are used in this classic approach. Due to these transformations, part of the information may be lost. The lost is greater, the more dynamically analyzed quantities change over time. The quantities of indicators can be predicted on the basis of historical data. The prediction is used, among others, in a dynamic approach of MCA.

The aim of the research work was the assessment of adaptability of 18 municipalities located in the subbasin of Nysa Kłodzka to the flood hazard. The research method adopted by the authors was based on a synthetic variable MCA linear ordering method in its classical and non-pattern approach. The ranking of considered municipalities was based on a set of values, specially created synthetic variable $A$, i.e. synthetic adaptability index (SAI). This variable was built with the use of diagnostic variables (indicators).

Construction of the set of diagnostic variables was two-step and it lied in selection of potential indicators. The criteria of choice are mainly of statistical nature. Potential diagnostic variables removed from the set include:

1. not very diverse, i.e. those for which the absolute value of the classic coefficient of variation is less than $10 \%$, as well as those of 
which vast majority of realizations is the same number,

2. too strongly correlated, i.e. with similar information potential, by eliminating one variable from each pair of too closely related indicators, however, cases of apparent correlation were not taken into account.

In the correlation analysis the critical value $r^{*}$ of Pearson's correlation coefficient was used [14, 21].

This value was determined from the formula:

$$
r^{*}=\sqrt{\frac{t^{2}}{t^{2}+n-2}},
$$

where:

$n$ - number of data, in this case $n=18$,

$t$ - value of statistics read from the Student's $t$ distribution table for the significance level $\alpha$ and for $n-2$ degrees of freedom, wherein it was adopted $\alpha=0.05$.

During the studies, too strongly or otherwise significantly correlated variables were considered those for which the absolute value of Pearson's correlation Heidelberg Laureate Forum.

These are the following postulates:

- depriving the units of measurement, in which the features are expressed,

- bringing the orders of variables magnitude to the state of comparability,

- equality of the lenght of variability intervals of values of all normalized features (constancy of the range) and equality of the lower and upper limits of their variability interval, in particular the interval $[0,1]$,

- the ability to normalize the features of positive and negative values or only negative,

- the ability to normalize the features of the value that equals zero,

- non-negativity of the value of the normalized features,

- the existence of simple formulas - within a given normalization formula - unifying nature of variables.

After choosing the method the normalization of the values of diagnostic variables has been made.

Finally, the values $a_{i}$ of the synthetic variable were determined as the sum of normalized values of diagnostic variables

$$
a_{i}=\sum_{j} z_{i j}, \quad i=1, \ldots 18,
$$

where $z_{i j}-$ normalized value of $j$-variable for $i$ municipality. The diagnostic variables, as assumed, were treated as an equivalent. The municipality achieves the higher position in the ranking, the higher value is achieved by the synthetic measure.

\section{Results and discussion}

- Among all 110 potential diagnostic variables there were 70 variables selected which are characterized by 14 determinants of adaptability of municipalities located in the sub-basin of Nysa Kłodzka (among 15 initially submitted to analysis).

- Ability to respond to crisis situations - (D4) is the only feature of SES (determinant) which was excluded from the analyses, because it was diagnosed by variables, which the majority of observations in the population of municipalities in the sub-basin of Nysa Kłodzka assumed the same values (table 2).

- In the next stage of studies on the assessment of adaptability of chosen Polish municipalities to the flood hazard, the observations of particular years should be analyzed, from the concerned period 2010-2016, the way to analyze the dynamics of the changes of value of every diagnostic variable.

- In the future, based on longer time series, the MCA can be applied in its dynamic approach.

\section{Results}

1. As a result of calculation we get $r^{*}=0.47$.

2. The normalization of the value of diagnostic variables was applied with the use of method of zero unitarization described with the formulas [21]:

- formula for stimulants:

$$
z_{i j}=\frac{x_{i j}-\min _{i}\left\{x_{i j}\right\}}{\max _{i}\left\{x_{i j}\right\}-\min _{i}\left\{x_{i j}\right\}},
$$

- formula for destimulants:

$$
z_{i j}=\frac{\max _{i}\left\{x_{i j}\right\}-x_{i j}}{\max _{i}\left\{x_{i j}\right\}-\min _{i}\left\{x_{i j}\right\}},
$$

where:

$z_{i j}$ - normalized value

$j$ - variable for $i$ - municipality.

This way of normalization has been chosen due to the fact it meets all the requirements given the most often to this type of methods [22-24].

3. It has been proposed to assess the adaptability of the municipality-SES to the flood hazard by determining a synthetic adaptability index (SAI) with the value given by the formula (2).

4. A created ranking of municipalities (figure 3) is characterized by LGUs with relatively small SAI variation (min. 22.9 - Skoroszyce; $\max$ 33,1 - Bystrzyca Kłodzka). 
Table 2. Selection of diagnostic variables as part of particular determinants and categories with assigned source of data.

\begin{tabular}{|c|c|c|c|c|}
\hline \multirow{2}{*}{$\begin{array}{l}\text { Cate- } \\
\text { go- } \\
\text { ries }\end{array}$} & \multirow{2}{*}{$\begin{array}{l}\text { Deter- } \\
\text { minan- } \\
\text { ts }\end{array}$} & \multicolumn{2}{|c|}{$\begin{array}{l}\text { Diagnostic } \\
\text { variables }\end{array}$} & \multirow{2}{*}{$\begin{array}{c}\text { Type } \\
\text { of } \\
\text { varia- } \\
\text { ble }\end{array}$} \\
\hline & & $\begin{array}{l}\text { output } \\
\text { set }\end{array}$ & $\begin{array}{c}\text { set after } \\
\text { selec- } \\
\text { tion }\end{array}$ & \\
\hline 1 & 2 & 3 & 4 & 5 \\
\hline \multirow{41}{*}{ K1 } & \multirow{12}{*}{ D1 } & $\mathrm{X} 1$ & & - \\
\hline & & $\mathrm{X} 2$ & $\mathrm{X} 2$ & $S$ \\
\hline & & $\mathrm{X} 3$ & & - \\
\hline & & $\mathrm{X} 4$ & & - \\
\hline & & X5 & & - \\
\hline & & $\mathrm{X} 6$ & X6 & S \\
\hline & & $\mathrm{X} 7$ & $\mathrm{X} 7$ & $\mathrm{~S}$ \\
\hline & & $\mathrm{X} 8$ & $\mathrm{X} 8$ & $\mathrm{D}$ \\
\hline & & X9 & $\mathrm{X} 9$ & $\mathrm{~S}$ \\
\hline & & $\mathrm{X} 10$ & & - \\
\hline & & $\mathrm{X} 11$ & & - \\
\hline & & $\mathrm{X} 12$ & $\mathrm{X} 12$ & $\mathrm{D}$ \\
\hline & \multirow{13}{*}{ D2 } & $\mathrm{X} 13$ & $\mathrm{X} 13$ & $\mathrm{D}$ \\
\hline & & $\mathrm{X} 14$ & & - \\
\hline & & $\mathrm{X} 15$ & & - \\
\hline & & $\mathrm{X} 16$ & & - \\
\hline & & $\mathrm{X} 17$ & & - \\
\hline & & $\mathrm{X} 18$ & & - \\
\hline & & X19 & & - \\
\hline & & $\mathrm{X} 20$ & $\mathrm{X} 20$ & $\mathrm{~S}$ \\
\hline & & $\mathrm{X} 21$ & $\mathrm{X} 21$ & $\mathrm{D}$ \\
\hline & & $\mathrm{X} 22$ & & - \\
\hline & & $\mathrm{X} 23$ & & - \\
\hline & & X24 & $\mathrm{X} 24$ & $\mathrm{~S}$ \\
\hline & & $\mathrm{X} 25$ & $\mathrm{X} 25$ & $S$ \\
\hline & \multirow{3}{*}{ D3 } & $\mathrm{X} 26$ & $\mathrm{X} 26$ & $\mathrm{~S}$ \\
\hline & & X27 & $\mathrm{X} 27$ & $S$ \\
\hline & & $\mathrm{X} 28$ & & - \\
\hline & \multirow{4}{*}{ D4 } & $\mathrm{X} 29$ & & - \\
\hline & & X30 & & - \\
\hline & & X31 & & - \\
\hline & & X32 & & - \\
\hline & \multirow{3}{*}{ D5 } & X33 & X33 & $\mathrm{S}$ \\
\hline & & X34 & X34 & S \\
\hline & & $\mathrm{X} 35$ & & - \\
\hline & \multirow{6}{*}{ D6 } & X36 & X36 & $\mathrm{S}$ \\
\hline & & X37 & X37 & $\mathrm{S}$ \\
\hline & & X38 & X38 & $\mathrm{S}$ \\
\hline & & X39 & & - \\
\hline & & $\mathrm{X} 40$ & X40 & $\mathrm{S}$ \\
\hline & & X41 & X41 & - \\
\hline \multirow{16}{*}{ K2 } & \multirow{12}{*}{ D7 } & $\mathrm{X} 42$ & $\mathrm{X} 42$ & $\mathrm{~S}$ \\
\hline & & $\mathrm{X} 43$ & $\mathrm{X} 43$ & S \\
\hline & & X44 & $\mathrm{X} 44$ & $\mathrm{~S}$ \\
\hline & & $\mathrm{X} 45$ & & - \\
\hline & & $\mathrm{X} 46$ & X46 & $\mathrm{S}$ \\
\hline & & $\mathrm{X} 47$ & $\mathrm{X} 47$ & $\mathrm{~S}$ \\
\hline & & X48 & $\mathrm{X} 48$ & $\mathrm{~S}$ \\
\hline & & X49 & X49 & $\mathrm{D}$ \\
\hline & & X50 & & - \\
\hline & & X51 & $\mathrm{X} 51$ & $\mathrm{~S}$ \\
\hline & & X52 & & - \\
\hline & & X53 & & - \\
\hline & \multirow{4}{*}{ D8 } & X54 & & - \\
\hline & & X55 & $\mathrm{X} 55$ & $\mathrm{D}$ \\
\hline & & X56 & & - \\
\hline & & X57 & X57 & $\mathrm{D}$ \\
\hline
\end{tabular}

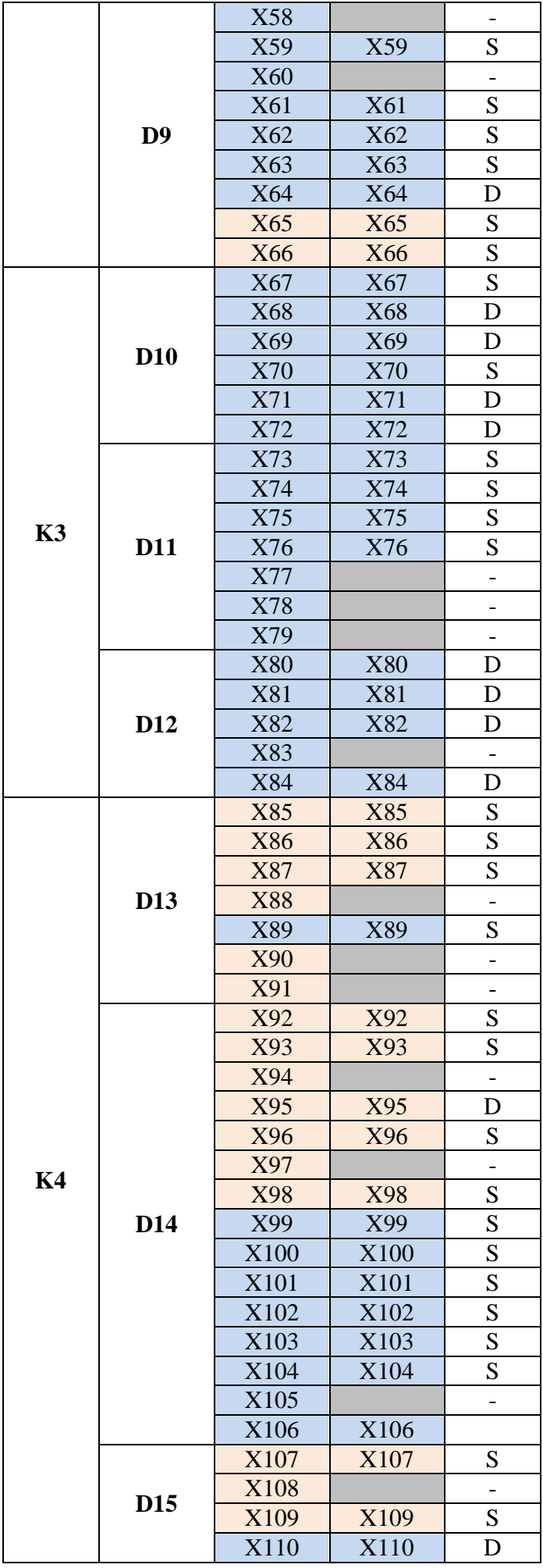

The source of obtaining data for the diagnostic variable:

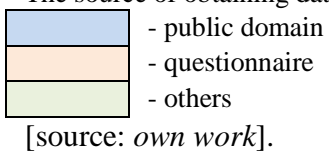

5. The comparative analysis of adaptability of researched municipalities, with the use of MCA, can contribute to the creation of the management tool enabling the assessment of particular components (features, categories) 
influencing on the process of adaptation of the municipality to the flood hazard. Such tool would allow the municipal authorities to select good practices applied by the partner municipalities. Implementation of these practices should lead to the improvement of municipal adaptability to the identified and predictable flood hazard.

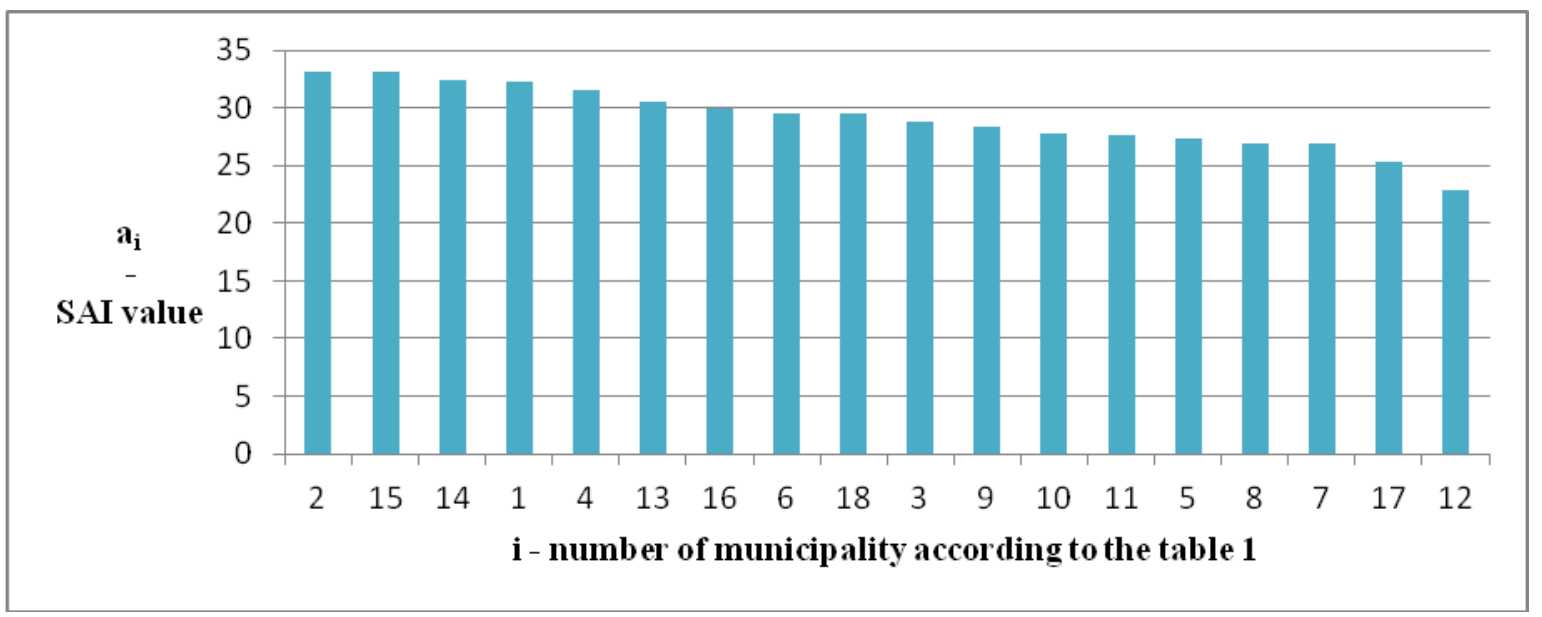

Fig. 3. The ranking of adaptability of municipalities-SES to the flood hazard created on the basis of the synthetic adaptability index (SAI) [source: own work].

1. This work was financially supported by project named: Development of Urban Adaptation Plans for cities with more than 100.000 inhabitants in Poland (Polish abbr. - MPA). The project is financed by the European Union from the Cohesion Fund and the state budget as part of technical assistance for the Infrastructure and Environment Program.

2. The authors presented the thesis of the research work at the scientific seminar concerned with meteorology, hydrology, water management and mathematical modelling in environmental science [24].

3. The conducted studies constitute the repercussion of the project Analysis of factor determining resilience of municipalities as social-ecological systems in the Nysa Kłodzka sub-basin. This project has been awarded by the Wprost Weekly and the POLPHARMA Foundation within the frames of the competition „Young \& Talented 2016: My idea for Poland", the winner of which was Grzegorz Dumieński.

\section{References}

1. IPCC - Intergovernmental Panel on Climate Change, Working Group II Report „Climate Change 2014: Impact, Adaptation, and Vulnerability. Part A: Global and Sectoral Aspects, (Cambridge University Press, New York, 2014)

2. H. Lorenc (eds.), Wptyw zmian klimatu na środowisko, gospodarkę i spoleczeństwo: zmiany, skutki $i$ sposoby ich ograniczania, wnioski dla nauki, praktyki inżynierskiej $i$ planowania przestrzennego. Tom 3: Klęski żywiołowe a bezpieczeństwo wewnętrzne kraju (Wydawnictwo IMGW-PIB, Warszawa, 2012)
3. Miejskie Plany Adaptacji do Zmian Klimatu (Polish abbr. - MPA), website project: http://44mpa.pl; access: 18.06.2018

4. J. Filaber, Ochrona bezpieczeństwa publicznego $w$ gminie (Wydawnictwo Difin, Warszawa, 2016)

5. Dyrektywa 2007/60/WE Parlamentu Europejskiego i Rady z dn. 23 października 2007 r. w sprawie oceny ryzyka powodziowego i zarządzania nim, OJ L 288 (2007)

6. Rozporządzenie Rady Ministrów $\mathrm{z}$ dnia 18 października 2016 r. w sprawie przyjęcia Planu zarządzania ryzykiem powodziowym dla obszaru dorzecza Odry (Dz. U. poz. 1938)

7. G. Dumieński, A. Lisowska, A. Tiukało [in review in Misc. Geogr. - Reg. Stud. on Dev.]

8. C. Folke, Glob. Environ. Chang. 16, 253-267 (2006)

9. W. Gądek, T. Tokarczyk, Infr. and Ecol. of Rur. Area. 4, 1507-1519 (2015)

10. The Odra River Basin Flood Protection (ORFPP), webside project: http://odrapcu.pl; access: 10.07.2018

11.T. Walczykiewicz, Metodyka kwantyfikacji wrażliwości jako jednego z czynników wplywajacych na ryzyko powodziowe; sprawozdanie $\mathrm{z}$ tematu badawczego DS.-W1.2, Kraków (2013)

12.P. Krajewski, M. Mackiewicz, E. Łaszkiewicz, A. Stefaniak, J. Stopolska, Mapa potencjatu społeczno-ekonomicznego gmin województwa pomorskiego: Raport metodologiczny i analityczny 
(Wyd. Urząd Marszałkowski Województwa Pomorskiego, Gdańsk, 2010)

13. Z. Hellwig, [in:] W. Welfe (eds.), Metody i modele ekonomiczno-matematyczne $\quad w$ doskonaleniu zarzadzania gospodarka socjalistyczna (PWE, 57, Warszawa, 1981)

14.T. Panek, Statystyczne metody wielowymiarowej analizy porównawczej (Oficyna Wydawnicza SGH, Warszawa, 2009)

15. T. Panek, J. Zwierzchowski, Statystyczne metody wielowymiarowej analizy porównawczej. Teoria izastosowania (Oficyna Wydawnicza SGH, Warszawa, 2013)

16. A. C. Rencher, Methods of Multivariate Analysis (John Wiley \& Sons, New York, 2002)

17. C. N. Giri, Multivariate Statistical Analysis (Marcel Dekker, New York, 2004)

18. A. Mastalerz-Kodzis, Stud. Ekon. Zesz. Nauk. Uniw. Ekon. w Katowicach 227 (2015)

19. M. Banaszewska, Stud. Oecon. Posnan. 4, 4 (2016)

20. U. Wagle, Multidimensional Poverty Measurement: Concepts and Applications (Springer, New York, 2008)

21. J. Dziechciarz (eds.), Ekonometria. Metody, przykłady, zadania (Wydawnictwo Akademii Ekonomicznej im. Oskara Langego we Wrocławiu, Wrocław, 2012)

22. K. Kukuła, Acta Sci. Acad. Ostrov. 4, 5-31 (1999)

23. M. Jarocka, Econ. and Manage. 1, 113-126 (2015)

24. K. Dębkowska, M. Jarocka, Acta Univ. Lodz. Folia Oecono. 286, 181-188 (2013)

25.L. Kuchar, A. Tiukało, Meteorol. Hydrol. and Water Manage. 6(2), 79-83 (2018) 